\title{
Pathophysiological mechanisms and pharmacological methods of prevention and treatment of bronchopulmonary dysplasia in preterm infants
}

\author{
Sławomir Jan Wątroba' ${ }^{1, A-C, F} \oplus$, Jarosław Bryda ${ }^{2, B, D-E \oplus ~}$ \\ 1 Department of Neonatology and Neonatal Intensive Care Unit, Independent Public Healthcare, Puławy, Poland \\ ${ }^{2}$ Department of Veterinary Hygiene, Voivodship Veterinary Inspectorate, Lublin, Poland \\ A - Research concept and design, B - Collection and/or assembly of data, C - Data analysis and interpretation, \\ $D$ - Writing the article, E-Critical revision of the article, F-Final approval of article.
}

Wątroba S. J, Bryda J. Pathophysiological mechanisms and pharmacological methods of prevention and treatment of bronchopulmonary dysplasia in preterm infants. J Pre-Clin Clin Res. 2019; 13(4): 170-178. DOI: 10.26444/jpccr/114123

\begin{abstract}
I Abstract
Introduction. Bronchopulmonary dysplasia (BPD) is a respiratory disease that is characterized by long-term respiratory failure and mainly affects premature infants with low birth weight (LBW), undergoing mechanical ventilation (MV) or requiring long-term oxygen therapy. In Europe, among newborns with birth weight $<1500 \mathrm{~g}$, the incidence of BPD is around $15 \%$.

Objective. The purpose of this review was to analyze the pathophysiological mechanisms involved in the development of BPD in premature newborns and to discuss the current possibilities of pharmacological prevention and treatment of BPD. Description of the state of knowledge. The BPD pathogenesis is multifactorial. Lung damage is the result of barotrauma and volutrauma due to high-performance MV, actions of reactive oxygen species (ROS) and infectious agents. Currently used methods of pharmacological treatment of severe forms of BPD are mainly based on systemic steroid therapy and can not be considered completely effective and free of side effects.

Conclusion. Despite the widespread use of proper pharmacotherapy and dynamic development of new methods of respiratory therapy, mortality in BPD is estimated at around 10\%-20\%. Infants with BPD are much more exposed to respiratory infections caused by respiratory syncytial virus (RSV), which may result in the development of bronchial hyperresponsiveness and bronchial asthma. Among children with BPD there are significantly higher cognitive and behavioral deficits compared to healthy children, and cerebral palsy is also significantly more common.
\end{abstract}

\section{Key words}

bronchopulmonary dysplasia, preterm infants, steroids, mechanical ventilation, metalloproteinases, respiratory failure

\begin{abstract}
Abbreviations
AA - arachidonic acid; AAP COFN - Committee on Foetus and Newborn of the American Academy of Pediatrics; ACTH adrenocorticotropin; ADH - vasopressin, antidiuretic hormone; ASMC - airway smooth muscle cells; BPD - bronchopulmonary dysplasia; BTN - betamethasone; CAT - catalase; CC10 - Clara cell $10 \mathrm{kDa}$ protein; CLD - chronic lung disease; COX cyclooxygenase; CPAP - continuous positive airway pressure; CPS FNC - Fetus and Newborn Committee of the Canadian Pediatric Society; DEX - dexamethasone; ELBW - extremely low birth weight; ENA-78 - epithelial protein activating neutrophils; EURAIL - Europe Against Immature Lung; FC - fludrocortisone; $\mathbf{F i O}_{2}$ - oxygen concentration in the breathing mixture; FTP - fluticasone propionate; GCSs - glucocorticosteroids; GM-CSF - granulocyte and macrophage colonystimulating factor; $\mathbf{G P x}$ - glutathione peroxidase; $\mathbf{H C}$ - hydrocortisone; $\mathbf{H O}$ - hydroxyl radical; $\mathbf{H O}_{2}$ - hydroperoxide radical; IFN- $\boldsymbol{\gamma}$ - gamma interferon; ILs - interleukins; IRDS - respiratory distress syndrome; IUGR - intrauterine growth retardation; IVH - intraventricular haemorrhage; LBW - low birth weight; LTs - leukotrienes; MAS - meconium aspiration syndrome; MIP1 - macrophage inflammatory protein-1; MMPs - metalloproteinases; MRI - magnetic resonance imaging; $\mathbf{M V}$ - mechanical ventilation; $\mathbf{n}$-CPAP - continuous positive airway pressure - nasal method; NEC - necrotizing enterocolitis; $\mathbf{O}_{\mathbf{2}}$ - superoxide anion; PD - prednisone; PDA - patent ductus arteriosus; PDGF - platelet-derived growth factor; PGs - prostaglandins; PIP - peak inspiratory pressure; PLA-2 - phospholipase A-2; PMA - postmenstrual age; PVL - periventricular leukomalacia; ROP - retinopathy of prematurity; ROS - reactive oxygen species; RSV - respiratory syncytial virus; SIP - spontaneous gastrointestinal perforation; SOD - superoxide dismutase; TGF-1 $\beta$ - transforming growth factor $1 \beta$; TIMP - tissue inhibitor of metalloproteinases; TNF- $\mathbf{a}$ - tumor necrosis factor $\mathbf{a}$.
\end{abstract}

\section{INTRODUCTION}

Bronchopulmonary dysplasia (BPD) is a respiratory disease characterized by long-term respiratory failure, and mainly

Address for correspondence: Sławomir Jan Wątroba, Department of Neonatology and Neonatal Intensive Care Unit, Independent Public Healthcare, Puławy, Bema 1, 24-100 Puławy, Poland

E-mail: watrobaslaw@gmail.com

Received: 12.09.2019; accepted: 10.11.2019; first published: 31.12 .2019 affects premature infants with a low birth weight (LBW), undergoing mechanical ventilation (MV) or requiring longterm oxygen therapy.

This review article analyzes the most important development risk factors and characterizes the most relevant BPD pathophysiological mechanisms. The currently recommended BPD treatment methods based on postnatal steroid therapy are also discussed and an attempt made to analyze potential BPD treatments currently in the experimental phase. 


\section{DEFINITION, EPIDEMIOLOGY AND ETIOPATHOGENESIS OF BPD}

Definition of BPD. BPD - also known as chronic prematurity lung disease (CLD) - refers to chronic respiratory disease characterized by long-term respiratory failure, which requires repeated use of respiratory support $[1,2]$.

In the case of newborns born before the 32 nd week of pregnancy, BPD is defined as the need for oxygen therapy before 28 days of age, or up to 36 weeks of postmenstrual age (PMA) inclusive $[1,3]$. The definition distinguishes 3 levels of bronchopulmonary dysplasia:

1) mild BPD, diagnosed when no additional oxygen supplementation is needed;

2) moderate $B P D$, in the case of oxygen demand, the concentration of which does not exceed $29 \%$ in the breathing mixture,

3) severe BPD, recognized when it is necessary to maintain continuous positive airway pressure (CPAP) or to use a breathing mixture with an oxygen concentration of $30 \%$ or more, or both procedures combined [4].

In the case of newborns born after the 32 nd week of pregnancy, BPD is defined as oxygen dependence in the first 28 days of life [4].

Table 1. Diagnostic criteria of bronchopulmonary dysplasia. BPD - bronchopulmonary dysplasia, $\mathrm{FiO}_{2}$ - oxygen concentration in the breathing mixture, nCPAP - continuous positive airway pressure - nasal method, PMA - postmenstrual age, PPV - positive pressure ventilation

\begin{tabular}{|c|c|c|}
\hline $\begin{array}{l}\text { Gestational } \\
\text { age }\end{array}$ & $<32$ weeks & $>32$ weeks \\
\hline \multirow[t]{2}{*}{$\begin{array}{l}\text { Study time } \\
\text { point }\end{array}$} & $\begin{array}{l}36 \text { weeks of PMA or day of } \\
\text { discharge home - whichever } \\
\text { occurs first }\end{array}$ & $\begin{array}{l}>28 \text { days but }<56 \text { days after } \\
\text { birth or day of discharge home - } \\
\text { whichever occurs first }\end{array}$ \\
\hline & \multicolumn{2}{|c|}{ Oxygen therapy for at least 28 days $\left(\mathrm{FiO}_{2}>21 \%\right)$ and: } \\
\hline mild BPD & $\begin{array}{l}\text { Breathing air at the } 36 \text { week of } \\
\text { PMA or on the day of discharge } \\
\text { home - whichever occurs first }\end{array}$ & $\begin{array}{l}\text { Breathing air on the } 56^{\text {th }} \text { day of } \\
\text { life or on the day of discharge } \\
\text { home - whichever occurs first }\end{array}$ \\
\hline $\begin{array}{l}\text { moderate } \\
\text { BPD }\end{array}$ & $\begin{array}{l}\text { The need for oxygen }<30 \% \\
\text { at the } 36 \text { week of PMA or on } \\
\text { the day of discharge home - } \\
\text { whichever occurs first }\end{array}$ & $\begin{array}{l}\text { The need for oxygen }<30 \% \text { on } \\
\text { the } 56^{\text {th }} \text { day of life or on the day } \\
\text { of discharge home - whichever } \\
\text { occurs first }\end{array}$ \\
\hline severe BPD & $\begin{array}{l}\text { Need to use oxygen }>30 \% \text { and/ } \\
\text { or positive pressure breathing } \\
\text { support (PPV/nCPAP) at the } 36 \\
\text { week of PMA or on the day of } \\
\text { discharge home - whichever } \\
\text { occurs first }\end{array}$ & $\begin{array}{l}\text { Need to use oxygen }>30 \% \\
\text { oxygen and/or positive pressure } \\
\text { breathing support (PPV/nCPAP) } \\
\text { on the } 56^{\text {th }} \text { day of life or on } \\
\text { the day of discharge home - } \\
\text { whichever occurs first }\end{array}$ \\
\hline
\end{tabular}

BPD, although it mainly concerns LBW premature infants undergoing mechanical ventilation (MV) or requiring longterm oxygen therapy, may also develop in full-term newborns who have meconium aspiration syndrome (MAS) or severe pneumonia. It can also occur in infants requiring prolonged ventilation due to heart defects, pulmonary hypertension, congenital defects or undergoing surgical interventions $[5,6]$.

Improvement in perinatal care as a whole has recently contributed to a significant increase in the survival rate of premature infants [7]. Despite the widely used prenatal supply of glucocorticoids (GCSs), respiratory failure is still a significant and serious health problem in this group of patients. The incidence of BPD is currently inversely proportional to birth weight and gestational age. The incidence of BPD among newborns with birth weight $<750$ g, requiring oxygen therapy in the 28th day of life, is in the range of $90 \%-100 \%$ and decreases to $54 \%$ among newborns showing dependence on oxygen at 36 weeks of post-contraceptive life. Among newborns with a birth weight of $750 \mathrm{~g}-999 \mathrm{~g}$, the BPD frequency fluctuates in the range of $50 \%-70 \%$ in the case of oxygen dependence at 28 days of life, and drops to $33 \%$ in the group of neonates dependent on oxygen at 36 weeks of life from fertilization. Patients with birth weight between $1,000 \mathrm{~g}-1,249 \mathrm{~g}$ develop dysplasia in $30 \%-60 \%$ in the case of oxygen dependence on day 28 , while oxygen dependence at 36 weeks of post-contraceptive life is associated in this group of patients with a $20 \%$ risk of developing BPD. In the case of oxygen dependence at 28 days of life, the risk of BPD is $6 \%-40 \%$, while oxygen dependence at 36 weeks of life from fertilization poses a risk of $10 \%$ in newborns with birth weight between $1,250 \mathrm{~g}-1,499 \mathrm{~g}[7,8]$.

In the USA, about $1.5 \%$ of newborns are born prematurely with a birth weight less than $1,500 \mathrm{~g}$. Of this group, approximately $20 \%$ develop BPD, which means 15,000 new cases each year. The differences in the adopted clinical management, ethnicity, race and socio-economic status are the reason for the large difference in the frequency of diagnosed cases of the disease. In female neonates and African Americans, the risk of BPD appears to be lower. In Europe, among newborns with birth weight $<1,500 \mathrm{~g}$, the incidence of BPD is about $15 \%[5,7]$.

Risk factors and pathophysiological mechanisms of BPD. Many factors, very often overlapping, play a role in BPD pathogenesis. Acute lung damage is the result of barotrauma and volutrauma, which occur when MV is used with high volumes and inspiratory pressures, as well as the action of infectious agents and toxic oxygen exposure $[5,9,10]$. Damaged cells release many pro-inflammatory cytokines that are intended to destroy and neutralize microorganisms and their toxins, as well as repair the resulting damage to lung parenchyma [11]. Inflammatory cytokines, which mainly include interleukins (IL): IL-1 $\beta$, IL-6, IL-8, tumor necrosis factor (TNF- $\alpha$ ), released from damaged cells, lead to changes in the permeability of the alveolar barrier of the lungs, which in turn results in the migration of inflammatory cells, mainly macrophages and polymorphonuclear leukocytes, into the intravesical space and intensification of inflammation, which deepens the destruction of lung-forming tissues. In addition to the release of growth factors, macrophages and leukocytes also exert lytic enzymes, including metalloproteinases (MMPs), leukotrienes (LTs) (mainly LT B4), TNF-a, chemotactic factors and IL-1 $\beta$, IL- 6 , IL- $8[5,11,12]$.

An additional damaging factor in the development of BPD is the high concentration of oxygen in the breathing mixture. When prolonged MV is used with high oxygen concentrations, IL- 8 production by macrophages and neutrophils increases, which has been shown to correlate positively with BPD risk $[10,13]$. Increased production of reactive oxygen species (ROS) (superoxide anion $\mathrm{O}_{2}$, hydrogen peroxide radical $\mathrm{HO}_{2}$, hydroxyl radical $\mathrm{HO}$ ) by phagocytic cells, with poorly developed premature infants, antioxidative enzyme systems, combined with lytic action of MMPs and pro-inflammatory cytokines, leads to inhibition of type I pneumocyte maturation, surfactant degradation, damage to the capillary-alveolar barrier and destruction of the pulmonary parenchyma, resulting in emphysema lesions 
$[2,5,12]$. Changes in the permeability of alveoli and impaired mucociliary transport, cause abnormalities in the removal of accumulated secretions and dead cells, which leads to the formation of vitreous membranes and obstruction of bronchioles, resulting in the occurrence of collapsed and emphysema areas in the lungs $[5,10,12]$.

Fibrosis and cell hyperplasia, which is a consequence of the action of cytokines, growth factors and impaired regenerative processes, leads to chronic changes in lung structures, disorders of fluid clearance and fluid retention in the lungs. Bronchial hypertrophy and their hyper-responsiveness occur, accompanied by hypertrophy of the muscular vessels. Pulmonary hypertension develops, lung compliance decreases, airway resistance increases, gas exchange disorders occur, leading to disturbance of the ventilation-to-perfusion ratio with hypercapnia and hypoxemia $[5,14-16]$.

The primary factor contributing to the development of BPD is immaturity of the lungs, which makes them more susceptible to the damaging effects of high volumes and inspiratory pressures during MV $[5,12,15,17]$.

Concerning premature infants, impaired activity of antioxidative enzymes, such as catalase (CAT), superoxide dismutase (SOD), glutathione peroxidase (GPx), results in the accumulation of ROS, and thus direct damage to the surfactant, destruction of type I pneumocytes and damage to the barrier capillary-vesicular $[2,5,18]$

Chorioamnionitis and perinatal infection, mainly caused by Ureaplasma urealyticum and Chlamydia trachomatis, positively correlate with the incidence of BPD in premature infants, most likely by stimulating the synthesis and secretion of epithelial cells of the respiratory system chemotactic factors for polymorphonuclear leukocytes, mainly ENA-78 epithelial protein and IL-8, as well as by inducing protein chemotactic factors released by macrophages, such as macrophage inflammatory protein (MIP-1) [5, 19-22]

Intrauterine infection or perinatal infection caused by Ureaplasma urealyticum causes an increased inflammatory response in the lungs, which disturbs the maturation and differentiation of alveoli and, on the other hand, significantly increases fibrosis $[23,24]$. In lung specimens collected from animals infected with Ureaplasma urealitycum, concentrations of interferon gamma (IFN- $\gamma$ ), TNF- $\alpha$, transforming growth factor (TGF-1 $\beta$ ) and IL-1 $\beta$, were significantly higher compared to healthy organisms $[25,26]$.

Severe forms of BPD are closely related to Gram (-) bacterial infections, in particular difficult to treat Klebsiella pneumoniae, Escherichia coli and Enterobacter cloacae infections. A weaker correlation is found for infections caused by Gram (+) bacteria, especially Staphylococcus spp [27-29].

Persistent right-left leakage at the level of the patent ductus arteriosus (PDA) and subsequent disturbances in blood distribution within organs, may result in an increased incidence of intraventricular haemorrhage (IVH), necrotizing enterocolitis (NEC), and retinopathy of prematurity (ROP) and also BPD [30-35]. Increased blood flow through the pulmonary vessels results in damage to the capillaries of the interstitial septa, and consequently, the migration of neutrophils to interstitial tissue $[11,35,36]$. In the case of MV using high inspiratory pressures, pulmonary distension and activation of macrophages within the alveoli and extravasated neutrophils from damaged capillaries may occur, resulting in increased production of pro-inflammatory cytokines, mainly IL-12 and TNF- $\alpha[11,37,38]$.
Excessive fluid intake in the early postnatal period also plays a role in the development of lung dysplastic changes. It impedes functional and later anatomical closure of the PDA and can also lead to stagnation of blood in the lung vessels, especially if accompanied by left ventricular myocardial insufficiency and low-line syndrome. Left ventricular failure leads to an increase in pressure and volume in the left atrium of the heart and pulmonary veins. Secondary right ventricular failure develops and when the hydrostatic pressure exceeds the colloid osmotic pressure in the blood, fluid enters the pulmonary parenchyma, which results in pulmonary oedema and lung stretch, and susceptibility are reduced $[5,39,40]$. In order to prevent iatrogenic overhydration in premature newborns, it is currently recommended to supply liquids in a volume of $60-80 \mathrm{ml} / \mathrm{kg}$ b.w./day on the first day of life of the newborn, which should be increased by about $20 \mathrm{ml} / \mathrm{kg}$ b.w./day up to a maximum value of $150 \mathrm{ml} / \mathrm{kg} \mathrm{b.w./day} \mathrm{[41].}$

Disorders of both pulmonary and systemic fluid balance, leading to pulmonary oedema and an increased risk of BPD, may also occur in the case of increased levels of vasopressin (antidiuretic hormone, ADH) in the blood serum of the newborn [42]. ADH is a polypeptide produced by large cellular neurons of the hypothalamus and stored and secreted by the posterior pituitary gland. Structurally, it is a cyclic nonapeptide with a molecular weight of 1,084 $\mathrm{Da}$, which has hemostatic and osmoregulatory activity [43]. The main stimulus for $\mathrm{ADH}$ secretion is stimulation of osmoreceptors and baroreceptors as a result of hyperosmolarity of extracellular fluid, hypovolaemia, hypotension and hypoglycaemia $[43,44]$. Regardless of receptor stimulation, $\mathrm{ADH}$ secretion increases as a result of the action of pro-inflammatory factors, mainly IL-6, IL-1 $\beta$ and TNF- $\alpha$, which play a key role in both acute and chronic lung injury associated with $\mathrm{BPD}[5,45,46] \mathrm{ADH}$ interacts through three types of receptors. Through the V1a receptor it causes vasoconstriction, through the V2 receptor it acts as an antidiuretic in the collecting coils, increasing sodium and water reabsorption, via the $\mathrm{V} 1 \mathrm{~b}$ receptor it stimulates the secretion of adrenocorticotropin (ACTH) [44, 46, 47]. $\mathrm{ADH}$ has its significant role both in utero and in the early postnatal period. It has an analgesic effect, stimulates the release of cortisol and noradrenaline by activating the hypothalamic-pituitary-adrenal axis during delivery [45]. The presence of ADH in the pituitary gland was demonstrated from 26-28 weeks of pregnancy, while increased secretion was found in the neonatal period, especially in the case of perinatal hypoxia $[45,48]$. Significantly higher levels of $\mathrm{ADH}$ in the blood of LBW neonates, intrauterine growth retardation (IUGR), intrauterine infection and sepsis, as well as neonates requiring respiratory support, have been shown. It is estimated that the concentration of $\mathrm{ADH}$, compared with new-born breathing spontaneously, is about one-and-a half times higher in newborns requiring noninvasive n-CPAP respiratory support, while twice as high in newborns requiring $\mathrm{MV}$, which is an additional risk factor for developing BPD through the action of ADH on increasing intravascular fluid volume, and the damaging effect of MV on lung forming tissues $[5,45]$. 


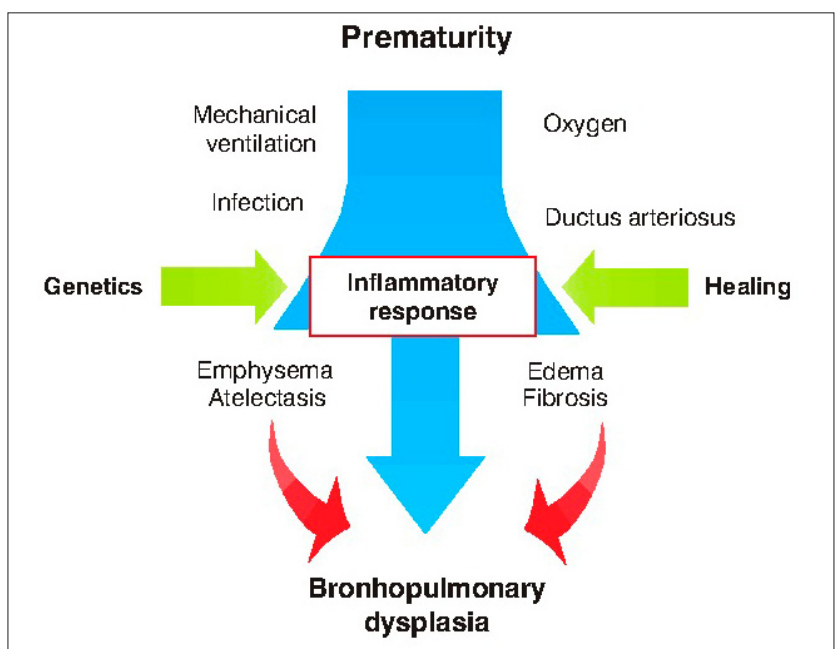

Figure 1 [49].

\section{CURRENT AND FUTURE PHARMACOLOGICAL METHODS OF PREVENTION AND TREATMENT OF BPD}

Methods of pharmacological treatment. In prophylactic procedure, attempts are being made to use retinol, caffeine citrate, inhaled nitric oxide, beta-adrenomimetics, ipratropium bromide, diuretics and in newborns with confirmed colonization or infected with Ureaplasma urealyticum, also macrolide antibiotics, mainly azithromycin $[50,51]$. According to evidence-based data, GCSs are the unique recommended method of prevention of BPD in children and can significantly improve the short-term prognosis of patients [52-56].

Postnatal steroid therapy of BPD. Postnatal GCSs supply is currently the most commonly used BPD prophylaxis method $[52,53]$. GCSs show a symptomatic effect on the development of inflammation without affecting its cause [57]. They reduce the accumulation of leukocytes and their adhesion to endothelial cells. They inhibit the breakdown of lysosomes, the process of phagocytosis, reduce the number of lymphocytes, eosinophils and monocytes, and also inhibit IgE-dependent release of inflammatory mediators such as histamine. They show an inhibitory effect on the synthesis and release of proinflammatory cytokines, such as IL-1, IL-2, IL-3, IL- 6 , interferon- $\gamma$ and TNF- $\alpha$. Through lipocortin-dependent inhibition of membrane phospholipase A-2 (PLA-2) enzyme activity, GCSs block the release of arachidonic acid (AA), the main substrate for COX-1 and COX-2 cyclooxygenases, and thus prevent the synthesis of inducible inflammatory mediators such as prostaglandins (PGs) and LTs [57-61].

Various GCSs supply patterns have been proposed for the prevention and treatment of BPD. Supply was used both early (in the first 7 days of life) and late (after the 14th day of life) [62-68].

Currently, dexamethasone (DEX) and hydrocortisone (HC) are most commonly used in BPD prophylaxis. There are also reports on the effectiveness of systemically administered betamethasone (BTN) [53, 69, 70].

$\mathrm{HC}$ is the main GCSs of the adrenal cortex obtained synthetically. At physiological concentration, it provides metabolic balance in the field of protein-carbohydrate metabolism, increases glycogen production and breakdown of proteins in the liver. It increases lipolysis and thus increases the concentration of fatty acids in the plasma. It exhibits relatively low mineralocorticoid activity compared to fludrocortisone (FC), retaining sodium and chlorine in the body. It has slight inhibitory properties on the hypothalamicpituitary-adrenal axis [71-73].

DEX is a synthetic GCSs, a fluorine derivative of prednisone (PD), with about 30 times stronger anti-inflammatory effect compared to HC. It has comparable effects on carbohydrateprotein-lipid metabolism with $\mathrm{HC}$, whereas it does not have mineralocorticoid activity [74]. BTN is a synthetic GCSs with a strong anti-inflammatory effect comparable to DEX and similarly mineral-corticosteroid-free. It strongly inhibits both the synthesis and release of proinflammatory cytokines, such as IL-1, IL-2, IL-3, IL-6, TNF- $\alpha$, IFN- $\gamma$ and granulocyte and macrophage colony stimulating factor (GM-CSF). After parenteral administration, $\tau_{1 / 2}$ BTN is about $40-50$ hours while its metabolism occurs in the liver, which in patients with impaired its function translates into a significant extension of its biological degradation [75].

Intravenous GCSs is recommended for prophylaxis of BPD because inhaled GCSs have not been shown to improve lung function parameters $[67,68,76-78]$. Inhaled steroid therapy can only be considered in neonates requiring respiratory support after the age of three weeks [76-78].

The supply of GCSs in the first seven days of life is not recommended, except in life-saving situations. GCSs supply after the 7th day of life in the lowest possible doses is assessed as much safer. The supply of low doses of GCSs at three weeks of life seems to be better because of the smaller number of neurological complications [64-66, 68].

According to current research, in the prevention of BPD the use of HC seems more favourable than DEX. There was no effect of HC therapy on the volume of the hippocampus, grey matter and white matter of the brain in magnetic resonance imaging (MRI), and no negative impact of HC therapy on the development of patients aged two years and at school age [79-81].

Based on the recommendations established by the Committee on Fetus and Newborn of the American Academy of Pediatrics (AAP COFN), Fetus and Newborn Committee of the Canadian Pediatric Society (CPS FNC) and the Europe Against Immature Lung (EURAIL) research group, GCSs supply is reserved only for patients with the most severe, progressive form of respiratory failure which shows resistance to other therapeutic methods [54-56]. In clinical practice, various GCSs supply patterns are used in BPD prophylaxis in premature infants.

Intravenous $\mathrm{HC}$ is most often administered on a six-day distribution. On the first and second day of treatment, the dose is $5 \mathrm{mg} / \mathrm{kg}$ b.w./day given in four divided doses per day, on the third and fourth day the dose is $3 \mathrm{mg} / \mathrm{kg}$ b.w./day in four divided doses, while on the fifth and sixth day the dose is $1 \mathrm{mg} / \mathrm{kg}$ b.w./day in four divided doses [82, 83].

Intravenous DEX administration is most often at a dose of $0.5 \mathrm{mg} / \mathrm{kg} \mathrm{b.w./day} \mathrm{for} \mathrm{three} \mathrm{days,} \mathrm{followed} \mathrm{by} 0.25 \mathrm{mg} / \mathrm{kg}$ b.w./day, $0.125 \mathrm{mg} / \mathrm{kg}$ b.w./day and $0.05 \mathrm{mg} / \mathrm{kg}$ b.w./day for three days. Another scheme provides for lower doses, namely $0.15 \mathrm{mg} / \mathrm{kg}$ b.w./day for three days, $0.10 \mathrm{mg} / \mathrm{kg}$ b.w./day for thrtee days, $0.05 \mathrm{mg} / \mathrm{kg}$ b.w./day for two days and $0.02 \mathrm{mg} /$ $\mathrm{kg}$ b.w./day for two days [84]. 
The supply of BTN in BPD was proposed by DeCastro et al. (2009) in a pilot study conducted among patients with severe respiratory failure meeting BPD criteria. The discussed scheme used intramuscular BTN at a dose of $0.125 \mathrm{mg} / \mathrm{kg}$ b.w./day in a single daily dose for three consecutive days [70]. The cited study compared therapeutic efficacy and the risk of side-effects of equivalent doses of BTN and DEX in neonates with severe BPD. No statistically significant differences were observed in the reduction of oxygen demand in both examined groups. In the BTN group, the peak inspiratory pressure (PIP) was reduced by $4 \mathrm{~cm} \mathrm{H}_{2} \mathrm{O}$ in $40 \%$ and $55 \%$ of newborns respectively 72 hours and seven days after the start of treatment, while in the DEX group the PIP decreased only in $7 \%$ of newborns at both points time. In the BTN group, a significantly higher weight gain was found, but a lower severity of hyperglycaemia compared to DEX. In the DEX group, sepsis and periventricular leukomalacia (PVL) were more common [70] (Tab. 2).

General steroid therapy in the prophylaxis of BPD, despite significant benefits, is reserved only for newborns with severe and progressive respiratory failure, and each GCSs supply should be carefully discussed with the patient's parents and supported by their written consent [54-56]. Numerous sideeffects of steroid therapy pose significant limitations in its use $[85,86]$.

Potential complications of steroid therapy. The stimulating effect on gastric secretion is an important risk factor for gastrointestinal perforation $[87,88]$. In a meta-analysis of the results obtained on the basis of multicentre clinical studies, Stark et al. found a statistically significant higher risk of spontaneous gastrointestinal perforation (SIP) in DEX-treated premature infants with extremely low birth weight (ELBW), which was $13 \%$ compared to $4 \%$ with a placebo supply [89]. Similar conclusions were drawn from the meta-analysis conducted by Gordon et al. [90].

In the neonatal group treated with DEX, there was also a significantly higher risk of developing hypertension compared to the placebo group - $27 \%$ vs $4 \%$, as well as a higher risk of hyperglycaemia requiring exogenous insulin supply $-23 \%$ vs $12 \%$ [89].

An extremely important complication of steroid therapy is the inhibitory effect on the development and maturation of brain nerve tissue, which is reflected in the child's neurodevelopment $[91,92]$.

A meta-analysis carried out by Stark showed that children who received DEX in the first seven days of life, at 36 weeks post-contraceptive age, had a smaller head circumference and lower body weight compared to children who did not use steroids [89].
Barrington [93] found more frequent prevalence of cerebral palsy, blindness and hearing loss $<60 \mathrm{~dB}$, based on a metaanalysis of the results of eight controlled, randomized trials involving a group of 679 newborns who received $\mathrm{HC}$ or DEX between $1-25$ days of age. In this group of patients, mental retardation (Index <70) examined on the Bayley Mental Development Scale was also demonstrated.

The risk of cerebral palsy among newborns receiving steroid therapy was $2.02 \%-2.86 \%$. Based on a meta-analysis by Barrington on 30 newborns treated with GCSs, four patients developed cerebral palsy in the first five years of life, while three others developed mental retardation. Among children receiving DEX, compared to the control group, a reduction of grey matter of the brain of up to $35 \%$ and slower weight gain was observed $[93,94]$.

Potential and experimental methods of pharmacological treatment. Current pathophysiological mechanisms of $\mathrm{BPD}$, based on the lytic activity of MMPs, increased the production of free oxygen radicals (ROS) by phagocytic cells and destruction of pulmonary parenchyma resulting from damage of capillary-alveolar barrier, inhibition of type I pneumocyte maturation and pathological processes of surfactant degradation, encourage the search for new, potentially effective BPD methods $[56,63,95]$.

Collagenolytic enzymes. In a study by Wątroba et al. [96], high serum MMPs activity was found to be associated with a reduced risk of BPD in the first days after birth. The study included 81 newborns, of which four groups were identified based on the duration of pregnancy:

Group $1(\mathrm{n}=18)-$ newborns from 24 weeks +0 days -27 weeks +6 days of gestational age;

Group $2(\mathrm{n}=18)$ - newborns from 28 weeks +0 days -31 weeks +6 days of gestational age;

Group $3(\mathrm{n}=27)$ - newborns from 32 weeks +0 days -35 weeks +6 days of gestational age;

Group $4(\mathrm{n}=17)$ - newborns from 36 weeks +0 days -41 weeks +6 days of gestational age.

BPD was diagnosed in $50 \%$ of patients in Group 1 and $11 \%$ in Group 2. An increase in MMP-2 activity in Group 2 and a decrease in the MMP-2 / TIMP-2 ratio in Group 1 compared to Group 2, and a significantly lower incidence $\mathrm{BPD}$ in patients with higher (above median) MMP-2/TIMP-2 values $(\mathrm{OR}=0.02, \mathrm{CI}=0.00-0.55 ; \mathrm{p}<0.05)$ was observed in Group 1. Decreased BPD in patients with higher MMP-3 concentration, higher MMP-9 activity and higher MMP-9/ TIMP-1 value did not reach statistical significance. However, the value of the MMP-9/TIMP-1 ratio, indirectly indicative of

Table 2. Recommended models of parenteral administration of glucocorticoids in bronchopulmonary dysplasia in preterm infants. b.w. - body weight, GCS - glucocorticoids, HC - hydrocortisone, i.m. - intramusculary, i.v.- intravenous

\begin{tabular}{|c|c|c|c|c|c|c|c|c|c|c|c|}
\hline \multirow{2}{*}{$\begin{array}{l}\text { Glucocorticoids and } \\
\text { type of administration }\end{array}$} & \multicolumn{10}{|c|}{ Day of treatment and dose of glucocorticoids per day (mg/kg b.w.)* } & \multirow[t]{2}{*}{ References } \\
\hline & 1 & 2 & 3 & 4 & 5 & 6 & 7 & 8 & 9 & 10 & \\
\hline Hydrocortisone i.v. & 5.0 & 5.0 & 3.0 & 3.0 & 1.0 & 1.0 & - & - & - & - & Lodygensky and al. 2005; Cambonie and al. 2009 \\
\hline Dexamethasone i.v. & 0.5 & 0.5 & 0.5 & 0.25 & 0.125 & 0.05 & - & - & - & - & Jefferies and al. 2012 \\
\hline Betamethasone i.m. & 0.125 & 0.125 & 0.125 & - & - & - & - & - & - & - & DeCastro and al. 2009 \\
\hline
\end{tabular}

*Daily doses are given in the table. The daily dose of $\mathrm{HC}$ is given in 4 divided doses. The remaining GCS is administered in one daily dose 
MMP-9 activity in vivo, was statistically lower in the youngest premature babies (Group 1), among whom the highest percentage of patients with BPD was demonstrated. The result suggests the involvement of MMP-9 in BPD prevention processes. Studies have shown a lower incidence of BPD for higher (above median) MMP-9 activity, MMP-9 / TIMP-1 and MMP-2/TIMP-2 ratios, and MMP-3 concentration.

Although only BPD odds ratio for the MMP-2/TIMP-2 ratio was statistically significant, it can be concluded that high serum MMPs activity in the first days after birth is associated with a reduced BPD risk. Conclusions from the conducted experiments may be the starting point for tests assessing the therapeutic use of exogenous enzymes from the group of MMPs in the prevention and treatment of BPD.

Recombinant human SOD. Zinc and copper-dependent human SOD (Zn/Cu-SOD, SOD-1 protein) is a protein containing copper and zinc atoms in its structure, that is abundantly present in the cytosol, nucleus, peroxisomes and mitochondrial intermembrane space of human cells. SOD1 protein is an enzyme with strong anti-oxidant properties, and its primary function is to reduce peroxide concentration at a steady state [97]. In newborns under 27 weeks of foetal age, experimental attempts are being made to endotracheal supply of recombinant human SOD-1 protein. At the endotracheal supply of SOD-1 protein used at 48-hour intervals, a reduction in the necessity to use bronchodilators and a significantly lower risk of complications requiring hospitalization during infancy were observed $[98,99]$.

Recombinant human CC10 protein. Clara cell $10 \mathrm{kDa}$ (CC10) protein is a protein produced by Clara cells that inhibits PLA-2 and has strong anti-inflammatory properties. It also plays an important role in regulating immune processes. Recombinant CC10 protein may inhibit platelet-derived growth factor (PDGF) induced cell viability, proliferation and migration [100]. CC10 has been shown to inhibit the chemotactic activity of neutrophils, phagocytes, monocytes, macrophages and fibroblasts [101, 102, 103]. In vitro studies have shown that CC10 blocks the production of secondary inflammatory mediators, in particular as a result of the inhibition of PLA-2 [104].

Studies have shown that PDGF-induced activation of cyclin D1 was inhibited by CC10, which resulted in inhibition of fibrosis and excessive, abnormal migration and proliferation of airway smooth muscle cells (ASMC) [100]. The antiinflammatory properties of this protein may have a potential beneficial role in the prevention of BPD $[105,106]$. Increased levels of oxidized and thus biologically inactive CC10 in ventilated premature babies ( $<29$ weeks of pregnancy) have been shown to correlate significantly with BPD development [107]. In research by Chandar et. al. on a group of 29 piglets aged 1-3 days subjected to MV, after a single intratracheal supply of recombinant CC10 protein at a dose of $5 \mathrm{mg} / \mathrm{kg}$ and $25 \mathrm{mg} / \mathrm{kg}$, both groups showed a significant improvement in lung compliance and oxygenation in 48-hour ventilated animals oxygen in the breathing mixture $\left(\mathrm{FiO}_{2}\right)$ equal to $100 \%$ with very good tolerance [108]. Although this study examined the safety and efficacy of a single dose of recombinant CC10 protein in acute lung injury, the results obtained may be the starting point for using CC10 protein to prevent BPD in the human population.

\section{LONG-TERM PROGNOSIS AND DISEASE COMPLICATIONS IN PATIENTS WITH BPD}

Despite the significant development of neonatology and constantly developing methods of BPD prophylaxis, its mortality is estimated at about $10 \%-20 \%$ in the first year of life. The risk of death increases in direct proportion to the duration of oxygen therapy and the advancement of ventilation methods and parameters $[5,109,110]$.

Symptoms of respiratory failure and radiological changes in the lungs, in seriously ill children, may persist for many years and significantly affect their daily functioning. Infants with chronic lung disease are at a much higher risk of respiratory infections, bronchiolitis and pneumonia compared to healthy children [111]. About 50\% of pneumonia and about $90 \%$ of bronchiolitis in children is caused by respiratory the syncytial virus (RSV), the infection of which in children with bronchopulmonary dysplasia is often associated with the need for hospitalization and MV, which in turn leads to pulmonary dysfunction. RSV infection in children with BPD also poses a significant risk of developing bronchial hyperreactivity and bronchial asthma [111-114].

Growth disorders are an important complication of BPD, inversely proportional to birth weight and dependent on the severity of BPD. Growth deficit mostly concerns body weight, while it is much less expressed in terms of head circumferences. The most visible growth retardation occurs within 20 months of the corrected age $[5,115]$.

BPD children have significantly higher cognitive and behavioural deficits compared to healthy children [91-93]. Among newborns born before the 28th week of gestational age, who required $\mathrm{MV}$ at 36 weeks of the corrected age, cerebral palsy also occurs significantly more often, compared with newborns breathing spontaneously $[93,95,116]$.

\section{CONCLUSIONS}

BPD is an undesirable consequence of MV replacement and prolonged oxygen therapy in premature newborns with respiratory failure. In the course of $\mathrm{BPD}$, bronchial reactivity increases, and thus their susceptibility to contraction increases. Bronchial hypertrophy is also accompanied by hypertrophy of the pulmonary arterioles, leading to the formation of pulmonary hypertension and right-ventricular heart failure.

BPD is a risk factor for serious infections, including RSV infections, which, despite the widespread use of prophylaxis in recent years, is still an extremely important problem in the care of a premature infants.

Postnatal supply of GCSs is currently the most commonly used method of BPD prophylaxis and treatment, which allows repeated reduction of ventilation parameters and earlier extubation of the patient, although it cannot be considered as a completely safe and completely effective method. Systemic supply of steroids is generally recommended for the prevention and treatment of BPD. In the studies cited in this review, the effectiveness of inhaled steroids has not been demonstrated, but from a practical point of view and own experience, in the case of mild BPD, the use of inhaled fluticasone propionate (FTP) allows for faster reduction of ventilation parameters, and allows earlier discontinuation of respiratory support. Due to the numerous side-effects, 
there is no doubt that systemic steroid therapy should only be considered in severe cases of BPD, in situations where there are real difficulties in extubating the patient. Attempts are also being made to use anti-oxidants, caffeine citrate, nitric oxide, beta-adrenomimetics, ipratropium bromide and diuretics to prevent and treat BPD.

This review did not address the topic of exogenous surfactant supply, commonly used for premature infants with respiratory distress syndrome (IRDS). Although this procedure is extremely effective in early syndromes associated with primary surfactant deficiency resulting from preterm labour and often allows for a rapid reduction of $\mathrm{FiO}_{2}$, however, in the case of already developed BPD, surfactant treatment loses its use and is not recommended. This is due to fundamental differences in the IRDS and BPD mechanisms. Experiments based on the role of MMPs in BPD seem to be of interest, and may be the starting point for tests assessing the therapeutic use of exogenous MMPs in BPD therapy. Perhaps BPD treatment with exogenous collagenolytic enzymes will become commonplace in the future.

\section{REFERENCES}

1. Ehrenkranz RA, Walsh MC, Vohr BR, Jobe AH, Wright LL, Fanaroff AA, et al. Validation of the National Institutes of Health consensus definition of bronchopulmonary dysplasia. Pediatrics. 2005; 116(6): 1353-1360.

2. Jobe AH, Ikegami M. Prevention of bronchopulmonary dysplasia. Curr Opin Pediatr. 2001; 13(2): 124-129.

3. Jobe AJ. The new BPD: an arrest of lung development. Pediatr Res. 1999; 46(6): 641-643.

4. Jobe AH, Bancalari E. Bronchopulmonary dysplasia. Am J Respir Crit Care Med. 2001; 163(7): 1723-1729.

5.Gadzinowski J. Neonatologia: Dysplazja oskrzelowo-płucna/ przewlekła choroba płuc [Neonatology: Bronchopulmonary dysplasia / chronic lung disease]. Warsaw, MediPage, 2015.

6. Taglauer E, Abman SH, Keller RL. Recent advances in antenatal factors predisposing to bronchopulmonary dysplasia. Semin Perinatol. 2018; 42(7): 413-424.

7. Głowacka E, Lis G. Dysplazja oskrzelowo-płucna - wczesne i odległe następstwa w zakresie układu oddechowego [Broncho-pulmonary dysplasia - early and distant sequelae of the respiratory system]. Pulmonol Alergol Pol. 2008; 76: 438-439.

8. Siffel C, Kistler KD, Lewis JFM, Sarda SP. Global incidence of bronchopulmonary dysplasia among extremely preterm infants: a systematic literature review. J Matern Fetal Neonatal Med. 2019; 1-11; doi:10.1080/14767058.2019.1646240.

9. Albertine KH. Pathogenesis of bronchopulmonary dysplasia: An unanticipated journey. The FASEB Journal. 2018; 32(1): 371.1-371.1.

10. Pasha A, Chen X, Zhou G. Bronchopulmonary dysplasia: Pathogenesis and treatment (Review). Exp Ther Med. 2018; 16(6): 4315-4321.

11. Willis GR, Fernandez-Gonzalez A, Anastas J, Vitali SH, Liu X, Ericsson $\mathrm{M}$, et al. Mesenchymal stromal cell exosomes ameliorate experimental bronchopulmonary dysplasia and restore lung function through macrophage immunomodulation. Am J Respir Crit Care Med. 2018; 197(1): 104-116.

12. Bourbon J, Boucherat O, Chailley-Heu B, Delacourt C. Control mechanisms of lung alveolar development and their disorders in bronchopulmonary dysplasia. Pediatr Res. 2005; 57(5Pt2): 38R-46R.

13. Laughon MM, Smith PB, Bose C. Prevention of bronchopulmonary dysplasia. SeminFetal Neonatal Med. 2009; 14(6): 374-382.

14. Piotrowski A. Niewydolność oddechowa noworodków- zapobieganie i leczenie: Powikłania niewydolności oddechowej noworodka [Neonatal respiratory failure - prevention and treatment: Complications of neonatal respiratory failure]. Bielsko-Biala, a-medica press, 2011.

15. Bancalari E, Abdenour GE, Feller R, Gannon J. Bronchopulmonary dysplasia: clinical presentation. J Pediatr. 1979; 95(5Pt2):819-823.

16. Ballabh P, Simm M, Kumari J, Califano C, Aghai Z, Laborada G, et al. Respiratory burst activity in bronchopulmonary dysplasia and changes with dexamethasone. PediatrPulmonol. 2003; 35(5): 392-399.
17. Pandya HC, Kotecha S. Chronic lung disease of prematurity: clinical and pathophysiological correlates. Monaldi Arch Chest Dis. 2001; 56(3): 270-275

18. Wang J, Dong W. Oxidative stress and bronchopulmonary dysplasia. Gene. 2018; 678: 177-183.

19. Morita M, Tanaka K, Matsumura S, Tamura M, Namba F. Perinatal factors associated with bubbly/cystic appearance in bronchopulmonary dysplasia: a nationwide, population-based cohort study in Japan. J Matern Fetal Neonatal Med. 2019; 1-6; doi:10.1080/14767058.2019. 1628945.

20. Chun J, Chun SH, Han YS, Sung TJ. Different degrees of maternal Ureaplasma colonization and its correlation with bronchopulmonary dysplasia in <32 weeks' preterm infants. Pediatr Neonatol. 2019; 60(4): 441-446.

21. Jouglet M, Wuillaume I, Buchs C, Reix P, Schweitzer C, Coutier L. Neonatal low respiratory tract chlamydia trachomatis infection: Diagnostic and treatment management. Respir Med Case Rep. 2019; 28:100852.

22. Ahmadi A, Ramazanzadeh R, Sayehmiri K, Sayehmiri F, Amirmozafari N. Association of Chlamydia trachomatis infections with preterm delivery; a systematic review and meta-analysis. BMC Pregnancy Childbirth. 2018; 18(1): 240.

23. dela Haye N, Hütten MC, Kunzmann S, Kramer BW. Bronchopulmonary dysplasia and ureaplasma: What do we know so far? Neonatal Medicine 2017; 24(1): 1-6.

24. Schelonka RL, Waites KB. Ureaplasma infection and neonatal lung disease. Semin Perinatol. 2007; 31(1): 2-9.

25. Viscardi RM, Atamas SP, Luzina IG, Hasday JD, He JR, Sime PJ, et al. Antenatal Ureaplasma urealyticum respiratory tract infection stimulates proinflammatory, profibrotic responses in the preterm baboon lung. Pediatr Res. 2006; 60(2): 141-146.

26. Baier RJ, Loggins J, Kruger TE. Monocyte chemoattractant protein-1 and interleukin-8 are increased in bronchopulmonary dysplasia: relation to isolation of Ureaplasma urealyticum. J Investig Med. 2001; 49(4): 362-369.

27. Cordero L, Ayers LW, Davis K. Neonatal airway colonization with gram-negative bacilli: association with severity of bronchopulmonary dysplasia. Pediatr Infect Dis J. 1997; 16(1): 18-23.

28. Pammi M, Lal CV, Wagner BD, Mourani PM, Lohmann P, Luna RA, et al. Airway microbiome and development of bronchopulmonary dysplasia in preterm infants: A Systematic Review. J Pediatr. 2019; 204: 126-133.

29. Vasilievna KM, Solomonovna KE, Demyanovna BE. The etiology of neonatal pneumonia, complicated by bronchopulmonary dysplasia. J Neonatal Perinatal Med. 2019; doi: 10.3233/NPM-17159.

30. Plagens-Rotman K, Bączyk G, Kubiak S. Krwawienia wewnątrzczaszkowe u noworodków z ekstremalnie mała urodzeniowa masą ciała [Intracranial haemorrhage in newborns with extremely low birth weight]. Now Lek. 2011; 80: 250-257.

31. Podraza W, Michalczuk B, Jezierska K, Domek H, Kordek A, Łoniewska B, et al. Correlation of retinopathy of prematurity with bronchopulmonary dysplasia. Open Med (Wars). 2018; 13: 67-73.

32. Poryo M, Boeckh JC, Gortner L, Zemlin M, Duppré P, EbrahimiFakhari D, et al. Ante-, peri- and postnatal factors associated with intraventricular hemorrhage in very premature infants. Early Hum Dev. 2018; 116: 1-8.

33. Janjindamai W, Prapruettrong A, Thatrimontrichai A, Dissaneevate S, Maneenil G, Geater A. Risk of necrotizing enterocolitis following packed red blood cell transfusion in very low birth weight infants. Indian J Pediatr. 2019; 86(4): 347-353.

34. Weisz DE, Giesinger RE. Surgical management of a patent ductus arteriosus: Is this still an option? Semin Fetal Neonatal Med. 2018; 23(4): 255-266.

35. Chen X, Li H, Qiu X, Yang C, Walther FJ. Neonatal hematological parameters and the risk of moderate-severe bronchopulmonary dysplasia in extremely premature infants. BMC Pediatr. 2019; 19(1): 138 .

36. Ahmed M, Miller E. Macrophage migration inhibitory factor (MIF) in the development and progression of pulmonary arterial hypertension. Glob Cardiol Sci Pract. 2018; 2018(2): 14.

37. Crosby LM, Waters CM. Epithelial repair mechanisms in the lung. Am J Physiol Lung Cell Mol Physiol. 2010; 298(6): L715-731.

38. Lachica CI, Begley A, Magee J, Manimtim W. Outcomes of Infants treated for BPD associated pulmonary hypertension and home mechanical ventilation. Pediatrics. 2018; 142(1): 187.

39. Blanca A, Duijts L, van Mastrigt E, Pijnenburg MW, Ten Harkel DD, Helbing WA, et al. Right ventricular function in infants with 
bronchopulmonary dysplasia and pulmonary hypertension: a pilot study. Pulm Circ. 2019; 9(1); doi:10.1177/2045894018816063.

40. Mirza H, Garcia JA, Crawford E, Pepe J, Zussman M, Wadhawan R, et al. Natural history of postnatal cardiopulmonary adaptation in infants born extremely preterm and risk for death or bronchopulmonary dysplasia. J Pediatr. 2018; 198: 187-193.

41. Borszewska-Kornacka M. Standardy opieki medycznej nad noworodkiem w Polsce: Żywienie pozajelitowe [Standards of medical care for the newborn in Poland: Parenteral nutrition]. Warsaw, MediaPress, 2013.

42. Amer R, Elsayed YN, Graham MR, Sikarwar AS, Hinton M, Dakshinamurti S. Effect of vasopressin on a porcine model of persistent pulmonary hypertension of the newborn. Pediatr Pulmonol. 2019; 54(3): 319-332.

43. Bankir L, Bichet DG, Morgenthaler NG. Vasopressin: physiology, assessment and osmosensation. J Intern Med. 2017; 282(4): 284-297.

44. Ramos AT, Tufik S, Troncone LR. Control of stress-induced ACTH secretion by vasopressin and $\mathrm{CRH}$ : Additional evidence. Neuropsychobiology. 2016; 73(3): 184-190.

45. Jarosz-Lesz A, Maruniak-Chudek I. Copeptin - stable C-terminal fragment of pre-provasopressin as a new stress marker in newborns. PostepyHig Med Dosw. 2015; 69: 681-689.

46. Caldwell HK. Young WS. Oxytocin and Vasopressin: Genetics and Behavioral Implications. In: Lim R, Lajtha R, editors. Handbook of neurochemistry molecular neurobiology. Springer; New York; 2006. p. 573-607.

47. Saleh N, Saladino G, Gervasio FL, Haensele E, Banting L, Whitley DC. A three-site mechanism for agonist/antagonist selective binding to vasopressin receptors. Angew Chem Int Ed Engl. 2016; 55(28): 8008-8012.

48. Hammock EA. Developmental perspectives on oxytocin and vasopressin. Neuropsychopharmacology. 2015; 40(1): 24-42.

49. Monte LF, Silva Filho LV, Miyoshi MH, Rozov T. Bronchopulmonary dysplasia. J Pediatr (Rio J). 2005; 81(2): 99-110.

50. Iyengar A, Davis JM. Drug therapy for the prevention and treatment of bronchopulmonary dysplasia. Front Pharmacol. 2015; 6:12; doi:10.3389/fphar.2015.00012.

51.Smith C, Egunsola O, Choonara I, Kotecha S, Jacqz-Aigrain E, Sammons H. Use and safety of azithromycin in neonates: a systematic review. BMJ Open. 2015; 5(12): e008194.

52.van de Loo M, van Kaam A, Offringa M, Doyle LW, Onland W. Corticosteroids for the prevention and treatment of bronchopulmonary dysplasia: an overview of systematic reviews. Cochrane Database Syst Rev. 2019; 2; doi:10.1002/14651858.CD013271.

53. Zeng L, Tian J, Song F, Li W, Jiang L, Gui G, et al. Corticosteroids for the prevention of bronchopulmonary dysplasia in preterm infants: a network meta-analysis. Arch Dis Child Fetal Neonatal Ed. 2018; 103(6): F506-F511.

54. Shinwell ES, Lerner-Geva L, Lusky A, Reichman B. Less postnatal steroids, more bronchopulmonary dysplasia: a population-based study in very low birthweight infants. Arch Dis Child Fetal Neonatal Ed. 2007; 92(1): F30-F33.

55. Watterberg KL. Postnatal steroids for bronchopulmonary dysplasia: where are we now? J Pediatr. 2007; 150(4): 327-328.

56. Yoder BA, Harrison M, Clark RH. Time-related changes in steroid use and bronchopulmonary dysplasia in preterm infants. Pediatrics. 2009; 124(2): 673-679.

57. Cain DW, Cidlowski JA. Immune regulation by glucocorticoids. Nat Rev Immunol. 2017; 17(4): 233-247.

58. Cruz-Topete D, Cidlowski JA. Glucocorticoids: molecular mechanisms of action. Immunopharmacology and Inflammation. Springer, Cham, 2018. 249-266.

59. Nocentini G, Ronchetti S, Bruscoli S, Riccardi C. The clinical pharmacology of past, present, and future glucocorticoids. Systemic Corticosteroids for Inflammatory Disorders in Pediatrics. Adis, Cham, 2015. 43-58.

60. Ge HZ, Han YE, Li Z, Chen XY, Liu SL, Xu AY. Effects of glucocorticoids on lipopolysaccharide-induced inflammatory responses in human middle ear epithelial cells and its mechanisms. Int J Clin Exp Pathol 2016; 9(11): 11404-11411.

61. Keränen T, Moilanen E, Korhonen R. Suppression of cytokine production by glucocorticoids is mediated by MKP-1 in human lung epithelial cells. Inflamm Res. 2017; 66(5): 441-449.

62. Doyle LW, Cheong JL, Ehrenkranz RA, Halliday HL. Early ( $<8$ days) systemic postnatal corticosteroids for prevention of bronchopulmonary dysplasia in preterm infants. Cochrane Database Syst Rev. 2017; 10; doi:10.1002/14651858.CD001146.
63. Doyle LW, Cheong JL, Ehrenkranz RA, Halliday HL. Late (> 7 days) systemic postnatal corticosteroids for prevention of bronchopulmonary dysplasia in preterm infants. Cochrane Database Syst Rev. 2017; 10; doi:10.1002/14651858.CD001145.

64. Halliday HL, Ehrenkranz RA, Doyle LW. Early postnatal (<96 hours) corticosteroids for preventing chronic lung disease in preterm infants. Cochrane Database Syst Rev. 2003; (1): CD001146.

65. Shah VS, Ohlsson A, Halliday HL, Dunn M. Early administration of inhaled corticosteroids for preventing chronic lung disease in ventilated very low birth weight preterm neonates. Cochrane Database Syst Rev. 2012; (5): CD001969.

66. Halliday HL, Ehrenkranz RA, Doyle LW. Moderately early (7-14 days) postnatal corticosteroids for preventing chronic lung disease in preterm infants. Cochrane Database Syst Rev. 2003; (1): CD001144.

67. Grier DG, Halliday HL. Corticosteroids in the prevention and management of bronchopulmonary dysplasia. SeminNeonatol. 2003; 8(1): 83-91.

68. Yates HL, Newell SJ. Postnatal intravenous steroids and long-term neurological outcome: recommendations from meta-analyses. Arch Dis Child Fetal Neonatal Ed. 2012; 97(4): F299-303.

69. Onland W, Merkus MP, Nuytemans DH, Jansen-van der Weide MC, Holman R, van Kaam AH, et al. Systemic hydrocortisone to prevent bronchopulmonary dysplasia in preterm infants (the SToP-BPD study): statistical analysis plan. Trials. 2018; 19(1): 178 .

70. DeCastro M, El-Khoury N, Parton L, Ballabh P, LaGamma EF. Postnatal betamethasone vs dexamethasone in premature infants with bronchopulmonary dysplasia: a pilot study. J Perinatol. 2009; 29(4): 297-304.

71. Olnes MJ, Kotliarov Y, Biancotto A, Cheung F, Chen J, Shi R, et al. Effects of systemically administered hydrocortisone on the human immunome. Sci Rep. 2016; 6: 23002.

72. Annane D, Renault A, Brun-Buisson C, Megarbane B, Quenot JP, Siami S, et al. Hydrocortisone plus fludrocortisone for adults with septic shock. N Engl J Med. 2018; 378(9): 809-818.

73. Tang K, Huang Y, Dong S, Gao P. Quantitative comparison of hydrocortisone and prednisone in the postoperative hormone therapy of hypercortisolism. Cancer Res. 2017; 77(13): 5642.

74. Chandrasekhar SS, Rubinstein RY, Kwartler JA, Gatz M, Connelly PE, Huang E, et al. Dexamethasone pharmacokinetics in the inner ear: comparison of route of administration and use of facilitating agents. Otolaryngol Head Neck Surg. 2000; 122(4): 521-528.

75. Petersen MC, Nation RL, McBride WG, Ashley JJ, Moore RG. Pharmacokinetics of betamethasone in healthy adults after intravenous administration. Eur J Clin Pharmacol. 1983; 25(5): 643-650.

76. Shah SS, Ohlsson A, Halliday H, Shah V. Inhaled versus systemic corticisteroids for the treatment of chronic lung disease in ventilated very low birth weight preterm infants. Cochrane Database Syst Rev. 2017

77. Rozycki HJ, Byron PR, Elliott GR, Carroll T, Gutcher GR. Randomized controlled trial of three different doses of aerosol beclomethasone versus systemic dexamethasone to promote extubation in ventilated premature infants. PediatrPulmonol. 2003; 35(5): 375-383.

78. Dimitriou G, Greenough A, Giffin FJ, Kavadia V. Inhaled versus systemic steroids in chronic oxygen dependency of preterm infants. Eur J Pediatr. 1997; 156(1): 51-55.

79. Rademaker KJ, Rijpert M, Uiterwaal CS, Lieftink AF, van Bel F, Grobbee DE, et al. Neonatal hydrocortisone treatment related to $1 \mathrm{H}-\mathrm{MRS}$ of the hippocampus and short-term memory at school age in preterm born children. Pediatr Res. 2006; 59(2): 309-313.

80. Rademaker KJ, Uiterwaal CS, Groenendaal F, Venema MM, van Bel F, Beek FJ, et al. Neonatal hydrocortisone treatment: neurodevelopmental outcome and MRI at school age in preterm-born children. J Pediatr. 2007; 150(4): 351-357.

81. Peltoniemi OM, Lano A, Puosi R, Yliherva A, Bonsante F, Kari MA, et al. Trial of early neonatal hydrocortisone: two-year follow-up. Neonatology. 2009; 95(3): 240-247.

82. Lodygensky GA, Rademaker K, Zimine S, Gex-Fabry M, Lieftink AF, Lazeyras F, et al. Structural and functional brain development after hydrocortisone treatment for neonatal chronic lung disease. Pediatrics. 2005; 116(1): 1-7.

83. Cambonie G, Mesnage R, Milési C, Rideau A, Veyrac C, Picaud JC. Hydrocortisone treatment for severe evolving bronchopulmonary dysplasia and cerebral haemodynamics. Arch Dis Child Fetal Neonatal Ed. 2009; 94(2): F154-F155.

84. Jefferies AL. Postnatal corticosteroids to treat or prevent chronic lung disease in preterm infants. Paediatr Child Health. 2012; 17(10): 573. 
85. Barrington KJ. The adverse neuro-developmental effects of postnatal steroids in the preterm infant: a systematic review of RCTs. BMC Pediatr. 2001; $1: 1$.

86. Ng PC. The effectiveness and side effects of dexamethasone in preterm infants with bronchopulmonary dysplasia. Arch Dis Child. 1993; 68(3): 330-336.

87. Oray M, Samra KA, Ebrahimiadib N, Meese H, Foster CS. Long-term side effects of glucocorticoids. Expert Opin Drug Saf. 2016; 15(4): 457-465.

88. Schäcke H, Döcke WD, Asadullah K. Mechanisms involved in the side effects of glucocorticoids. Pharmacol Ther. 2002;96(1): 23-43.

89. Stark AR, Carlo WA, Tyson JE, Papile LA, Wright LL, Shankaran S, et al. Adverse effects of early dexamethasone treatment in extremelylow-birth-weight infants. N Engl J Med. 2001; 344(2): 95-101.

90. Gordon PV, Young ML, Marshall DD. Focal small bowel perforation: an adverse effect of early postnatal dexamethasone therapy in extremely low birth weight infants. J Perinatol. 2001; 21(3): 156-160.

91. Whitelawa A, Thoresenb M. Antenatal steroids and the developing brain. Arch Dis Child Fetal Neonatal Ed. 2000; 83(2): F154-F157.

92. Huang WL, Beazley LD, Quinlivan JA, Evans SF, Newnham JP, Dunlop SA. Effect of corticosteroids on brain growth in fetal sheep. Obstet Gynecol. 1999; 94(2): 213-218.

93. Barrington KJ. Postnatal steroids and neurodevelopmental outcomes: a problem in the making. Pediatrics. 2001; 107(6): 1425-1426.

94. Halliday HL. Early postnatal dexamethasone and cerebral palsy. Pediatrics. 2002; 109(6): 1168-1169.

95. Anderson PJ, Doyle LW. Neurodevelopmental outcome of bronchopulmonary dysplasia. Semin Perinatol. 2006; 30(4): 227-232.

96. Watroba S, Kocot J, Bryda J, Kurzepa J. Serum activity of MMP-2 and MMP-9 and stromielisin-1 concentration as predictors in the pathogenesis of bronchopulmonary dysplasia in preterm neonates. Postepy Hig Med Dosw (Online). 2019; 73, in press.

97. Valentine JS, Doucette PA, Zittin Potter S. Copper-zinc superoxide dismutase and amyotrophic lateral sclerosis. Annu Rev Biochem. 2005; 74: 563-593.

98. Gentyala RR, Ehret D, Suresh G. Superoxide dismutase for preventing bronchopulmonary dysplasia (BPD) in preterm infants. Cochrane Database Syst Rev. 2019; 1; doi:10.1002/14651858.CD013232.

99. Sherlock LG, Trumpie A, Hernandez-Lagunas L, McKenna S, Fisher S, Bowler R. Redistribution of extracellular superoxide dismutase causes neonatal pulmonary vascular remodeling and $\mathrm{PH}$ but protects against experimental bronchopulmonary dysplasia. Antioxidants (Basel). 2018; 7(3). pii: E42.

100. Wei Y, Xu YD, Yin LM, Wang Y, Ran J, Liu Q, et al. Recombinant rat CC10 protein inhibits PDGF-induced airway smooth muscle cells proliferation and migration. Biomed Res Int. 2013; 2013: 690937. doi $10.1155 / 2013 / 690937$.

101. Vasanthakumar G, Manjunath R, Mukherjee AB, Warabi H, Schiffmann E. Inhibition of phagocyte chemotaxis by uteroglobin, an inhibitor of blastocyst rejection. Biochem Pharmacol. 1988; 37(3): 389-394.
102. Hayashida S, Harrod KS, Whitsett JA. Regulation and function of CCSP during pulmonary Pseudomonas aeruginosa infection in vivo. Am J Physiol Lung Cell Mol Physiol. 2000; 279(3): 452-459.

103. Lesur O, Bernard A, Arsalane K, Lauwerys R, Bégin R, Cantin A, et al. Clara cell protein (CC-16) induces a phospholipase A2-mediated inhibition of fibroblast migration in vitro. Am J Respir Crit Care Med. 1995; 152(1): 290-297.

104. Dierynck I, Bernard A, Roels H, De Ley M. The human Clara cell protein: biochemical and biological characterisation of a natural immunosuppressor. Mult Scler. 1996; 1(6): 385-387.

105. Davis JM, Pilon AL, Shenberger J, Breeze JL, Terrin N, Mazela J, et al. The role of recombinant human CC10 in the prevention of chronic pulmonary insufficiency of prematurity. Pediatr Res. 2019; 86(2): 254-260.

106. Pilon AL, Winn ME, Clayton RS, Hariprakasha H. Modification of CC10 protein by reactive oxygen species: A novel anti-inflammatory mechanism. Am J Respir Crit Care Med. 2016; 193: A5907.

107. Ramsay PL, DeMayo FJ, Hegemier SE, Wearden ME, Smith CV, Welty SE. Clara cell secretory protein oxidation and expression in premature infants who develop bronchopulmonary dysplasia. Am J Respir Crit Care Med. 2001; 164(1): 155-161.

108. Chandra S, Davis JM, Drexler S, Kowalewska J, Chester D, Koo HC, et al. Safety and efficacy of intratracheal recombinant human Clara cell protein in a newborn piglet model of acute lung injury. Pediatr Res. 2003; 54(4): 509-515.

109. DeVries LB, Heyne RJ, Ramaciotti C, Brown LS, Jaleel MA, Kapadia VS, et al. Mortality among infants with evolving bronchopulmonary dysplasia increases with major surgery and with pulmonary hypertension. J Perinatol. 2017; 37(9): 1043-1046.

110. Steurer MA, Nawaytou H, Guslits E, Colglazier E, Teitel D, Fineman JR, et al. Mortality in infants with bronchopulmonary dysplasia: Data from cardiac catheterization. Pediatr Pulmonol. 2019; 54(6): 804-813.

111. Borszewska-Kornacka M. Standardy opieki medycznej nad noworodkiem w Polsce: Profilaktyka zakażeń RSV [Standards of medical care for the newborn in Poland: Prevention of RSV infections]. Warsaw, Media-Press, 2013.

112. Barr FE, Graham BS, Mallory GB. Respiratory syncytial virus infection: Prevention. UpToDate. 2018; www.uptodate.com/contents/respiratorysyncytial-virus-infection-prevention\#H104280568 (access: 2019.09.01).

113. Chi H, Chung CH, Lin YJ, Lin CH. Seasonal peaks and risk factors of respiratory syncytial virus infections related hospitalization of preterm infants in Taiwan. PLoS One. 2018; 13(5): e0197410.

114. Pérez Tarazona S, Solano Galán P, Bartoll Alguacil E, Alfonso Diego J. Bronchopulmonary dysplasia as a risk factor for asthma in school children and adolescents: A systematic review. Allergol Immunopathol (Madr). 2018; 46(1): 87-98.

115. Thomas S, Murthy P, Saigal S. Long-term outcomes of newborns with bronchopulmonary dysplasia. Manual of Neonatal Respiratory Care. Springer, Cham, 2017. 657-661.

116. Gou X, Yang L, Pan L, Xiao D. Association between bronchopulmonary dysplasia and cerebral palsy in children: a meta-analysis. BMJ Open. 2018; 8(9): e020735. 